\title{
Change Detection of Olive Trees Distribution using Semi-Automated Object Based Image Classification
}

\author{
Ahmed Harb Rabia ${ }^{1 *}$, Emad Fawzy Abdelaty ${ }^{1}$, Maha Lotfy Elsayed ${ }^{2}$, Assem A. A. Mohamed ${ }^{2}$, \\ Fatma Wassar ${ }^{3,4}$, Edoardo Fiorillo ${ }^{5}$, Andria Di Vecchia ${ }^{6}$, Vieri Tarchiani ${ }^{7}$
}

\begin{abstract}
Geographic object-based image analysis (GEOBIA) is a remote sensing technique that characterize image pixels into objects based on spectral, temporal, and spatial characteristics. It is a useful technique for land use classification and change detection. In this study, a land use and land cover classification and change detection was caried out at Oum Zessar watershed in the Medenine governorate of Tunisia to estimate the changes in olive trees distribution using high resolution satellite images of 2005 and 2013 and the geographic object-based image analysis technique (GEOBIA). Eight different vegetation indices (VIs) were used to enhance the classification process. The multi-resolution segmentation algorithm was selected as the main segmentation algorithm through the entire classification process. Results showed that Normalized Difference Vegetation Index (NDVI), Normalized Near Infrared (NNIR) and Ratio Vegetation Index (RVI) had high significance to be used for the recognition of the different objects and classes. In addition, results showed that olive tree canopy increased by almost $60 \%$ from 39 ha to 62 ha in the study area during the period from 2005 to 2013 . In addition, analysis of the classification results showed that the number of the trees objects increased by $22.7 \%$ from the year 2005 to 2013 . This study showed the potential of Geographic objectbased image analysis" (GEOBIA) technique in classifying land use in general and in detecting olive trees objects specifically.
\end{abstract}

Keywords: Remote Sensing, GEOBIA, Olive, Vegetation indices, Land Use Change.

DOI: 10.21608/asejaiqjsae.2021.205324

${ }^{1}$ Department of Natural Resources \& Agricultural Engineering,

Faculty of Agriculture, Damanhur University, Damanhur, Egypt.

${ }^{2}$ Central Laboratory for Agricultural Climate (CLAC),

Agricultural Research Centre, Giza, Egypt

${ }^{3}$ Higher Institute of Water Sciences \& Techniques,

University of Gabès, Gabès, Tunisia

${ }^{4}$ Institute of Arid Regions, Gabès, Tunisia

${ }^{5}$ IBE-CNR, via Gobetti 101, 40129 Bologna, Italy

${ }^{6}$ IBE-CNR, via dei Taurini 19, 00185 Rome, Italy

${ }^{7}$ IBE-CNR, via Madonna del Piano 10, 50019 Sesto F.no, Florence, Italy

* Corresponding author. E-mail: ahmedrabia@agr.dmu.edu.eg (A. H. Rabia)

Received October 05, 2021, Accepted, November09, 2021.

\section{INTRODUCTION}

Tunisia is the most important olive oil producer in the Southern Mediterranean basin. Globally, Tunisia occupies the second world rank for the production of olive oil after the European Union, with a mean production of about 165000 tons of olive oil, more than $6 \%$ of the world production. This is a thousand-year-old crop. Phoenicians were the first to introduce this crop in North Africa; the other Mediterranean civilizations continued its expansion. Indeed, since XIth century AC., and even before the foundation of Carthage, the olive-tree crops were developed in the entire Mediterranean basin. Production analysis of fruits and vegetables production structure in Tunisia shows that olives, citrus, and tomato production are among most strategic agricultural productions (Allaya et al., 2001). More than $30 \%$ of its arable lands are devoted to olive crop since it covers about 1.7 million ha comprising about 75 million olive trees. Olive groves at Oum Zessar watershed in the Medenine governorate of Tunisia represents the key crop in the area and in several cases the only cultivation able to grow in these environmental conditions (arid zone). Olive trees are cultivated in widely varied climatic conditions from north to south and it is the main domestic source of edible oils. The international trade of olive oil represents $50 \%$ of the total agricultural exports. A decrease of $65 \%$ of the national production of olive oil during the 2013-2014 season compared to the previous season was noticed. Olives, a mainly rainfed production, plays a vital role in the social and economic life of Tunisia. Over the last ten years noteworthy fluctuations in olive production have been observed. Investigating 
the impacts of such fluctuations on socio-economic sector is thereby with major importance. Vulnerability assessment is also needed to investigate factors with major impacts on olives production. Desertification is an on-going phenomenon, aggravated by anthropogenic pressures, which are driven by changes in socioeconomic policies and population growth. Many studies revealed that in the last few decades landscape transformation rate was increased significantly (Antrop, 2005; Ellis and Pontius, 2013; Ewert et al., 2005). Therefore, studying the factors that control these changes and their impacts become extremely essential for those how are involved in biodiversity conservation, land use planning, and landscape ecology (Etter et al., 2006), and defending water resources management plans (Ripa et al., 2006).

The term "Land use and land cover change (LULCC)" refers to changes made to the Earth's surface through the human impact that is known as anthropogenic activities (Ellis and Pontius, 2013) or by other natural factors. There are several definitions of land cover (Meyer et al., 1994) and land use (Jansen, 2006). In this study, land cover refers to "the observed (bio) physical cover on the earth's surface" (Gregrio and Jansen, 2000); while land use defines how the people use this part of the earth's surface (Cihlar and Jansen, 2001). Historically, humans have made many changes arising from the need to exploit resources and through agricultural expansion. However, the present rate of land use and land cover change (e.g. transformation from agricultural or forested areas to urban areas) is much greater than ever recorded previously, resulting in rapid changes to the ecosystem at local to global scales. The spatial analysis of land use and land cover change comprises the use of historical maps or satellite images to judge against recent ones. Nowadays, satellite remote sensing is the most usable data source for recognition, determination, and mapping land use and land cover (LULC) outlines and changes because of its accurate geo-referencing procedures, digital format suitable for computer processing and successive data acquisition, (Chen et al., 2005; Jensen, 1996; Lu et al., 2004).

Geographic object-based image analysis (GEOBIA) is technique of remote sensing and Geographic Information Science in which image pixels are segmented into objects of similar spectral, temporal and spatial characteristics. Unlike pixel-based technique, GEOBIA uses the object properties such as roundness, square fit, and texture in addition to many other properties to improve classification results. GEOBIA technique can be divided into two main steps; segmentation and classification. In the segmentation process, adjacent pixels of similar spectral and spatial characteristics are grouped into single objects. Then, in the classification process, the generated objects will be assigned to different classes based on the characteristics of the individual objects (Rabia and Terribile, 2013)

In this study, land use and land cover change detection classification has been done in order to study changes in the distribution of olive trees using high resolution satellite images of 2005 and 2013 and the geographic object-based image analysis technique (GEOBIA).

\section{MATERIALS AND METHODS}

\subsection{Study Area Description:}

Oum Zessar Watershed is located in Medenine governorate, in south Tunisia and has 36,000 hectares surface area (Adham et al., 2016b). The watershed area is part of the Jeffara of Tunisia and is characterized by a low arid Mediterranean climate with an average annual rainfall of $160-220 \mathrm{~mm}$ which is received on average of 30 days a year (Adham et al., 2016a; Derouiche, 1997). The coldest months are December, January and February when occasional frosts occur and temperatures can fall to $-3^{\circ} \mathrm{C}$ and June, July and August are the hottest months when temperatures reach $48^{\circ} \mathrm{C}$. Temperatures are affected by the proximity of the sea in the north and the higher altitudes in the south. The climate in the upper catchment is drier with temperate conditions in winter and less arid, with mild winters in the lower catchment area. The watershed is typically an agro-pastoral interlocked area, with crop cultivation expanding rapidly in flatter areas and marginal rangelands (Adham et al., 2019). Expansion of crop lands has had negative effects on native rangelands, as native vegetation declines and animals have less and less area left to graze. Oum Zessar watershed is a good representative of the whole zone of the southeastern region, and therefore, extrapolation of case study results is possible under some basic assumptions. Oum Zessar can be considered the most important watershed in the region because it has the largest area $\left(367 \mathrm{~km}^{2}\right)$ and perimeter $(118 \mathrm{~km})$ with a very dense stream system. The area is characterized by irregular rainfall, which has significant impacts on natural resources management and agricultural production. The succession of dry years, irregularity of rain and occurrence of extreme events are key factors of land degradation in the area. The effects are less water for plant growth, lower biomass production and grain yield, and as a consequence less protection of soils by vegetation (Ouessar, 2007). In general, Oum Zessar has the following key biophysical and socio-economic characteristics: i) degraded dry-lands; ii) low rainfall; iii) water scarce; iv) accelerated expansion of rain-fed and irrigated agriculture for olive trees and cereals; v) high demand for irrigation; vi) mixed communal and private agrarian system; vii) rapid population growth 
and urbanization. Land use map for the Oum Zessar watershed was obtained from the Institute of Arid Regions (IRA) in Medenine, Tunisia for the year of 2004 (Figure 1). The map shows that the watershed has different land uses including agricultural lands (cereals, olives of plains, and olives of the mountains) and rangelands (Halophyte ranges, rangelands of the mountains, and rangelands of the plains). The geophysical zones of the watershed are as follows:

- Upstream covers the mountain zones, corresponding the administrative territory of BeniKhedache delegation.

- Mid-stream starts from the Bhayra, Chouamakh regions at the foot of the mountain zone which is part of BeniKhedache delegation and northern Medenine delegation.

- Downstream starts from Koutine to the sea (Boughrara Golf), corresponding the administrative territory of SidiMakhlouf delegation.

\subsection{Land use and land cover change detection:}

Study of land use change was performed on a selected area in the watershed of about $30 \mathrm{~km}^{2}$ (Figure
2). High resolution satellite images of the years 2005 and 2013 for this area were used for the analysis.

The work was divided into three steps. First the satellite images were preprocessed to be ready for the land use and land cover classification. In this step, eight different vegetation indices (VIs) were applied to the satellite images in order to enhance the classification process (Table 1) (Baret and Guyot, 1991; Gitelson et al., 2002). Then, an image classification process was performed on both the satellite images from 2005 and 2013 in order to obtain land use and land cover maps for both acquired dates. The image classification was carried out using the "Geographic object based image analysis" (GEOBIA) technique (Figure 3) through eCognition software $@$ (Rabia and Terribile, 2013). The calculation of homogeneity criterion $(\sigma)$ (Figure 4 ) in eCognition 8.7 is based on selecting a scale parameter value and choosing weights for four other criteria (shape, color, smoothness and compactness), which are embedded in the algorithm. Finally, a spatial analysis was done in ArcGIS software (c) by Esri (ESRI ArcGIS, 2011) in order to detect the changes in olive trees plantation during the period from 2005 to 2013.

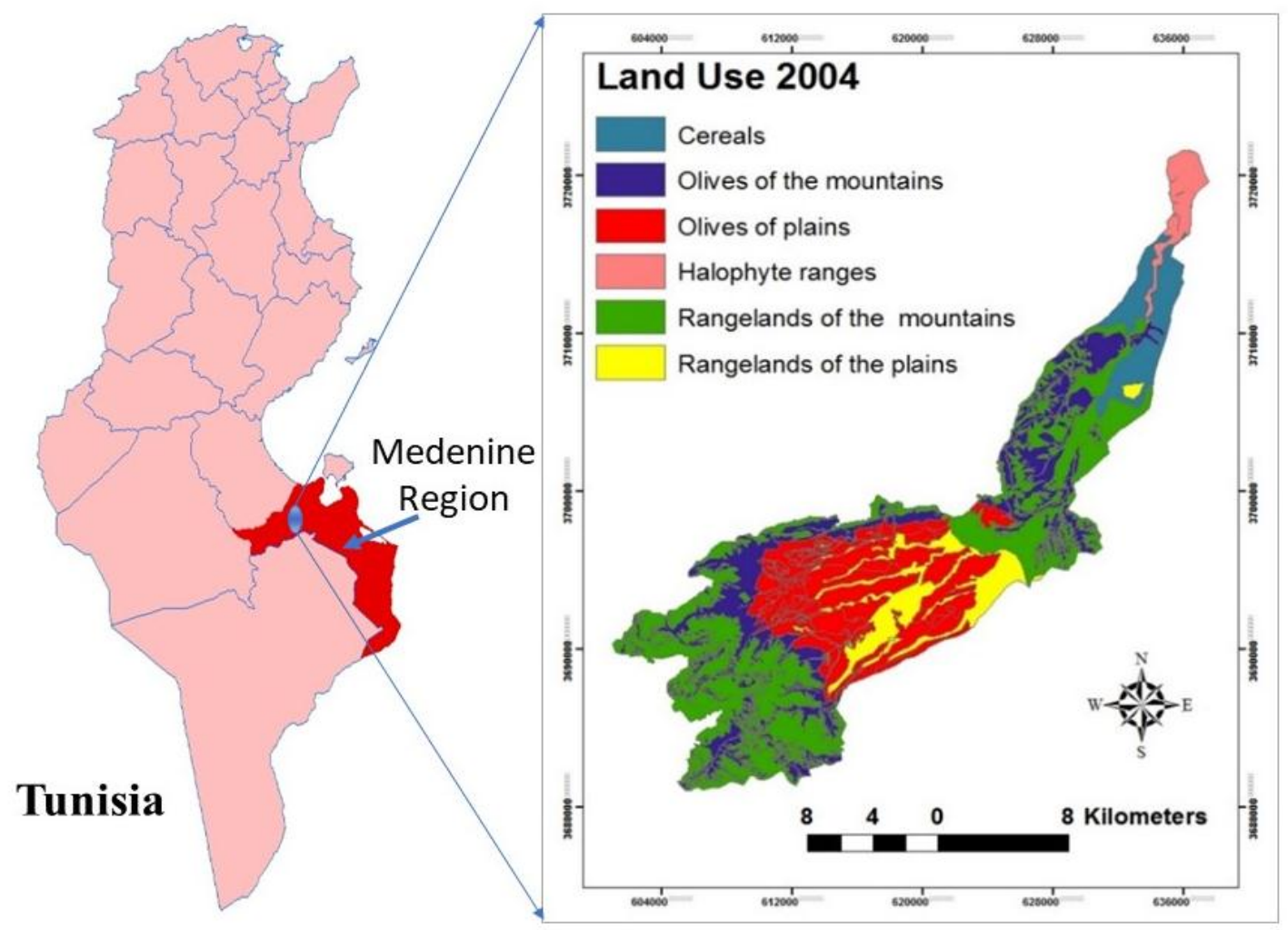

Figure 1. Study area location and land use map of Oum Zessar watershed in the Medenine Region, Tunisia. 


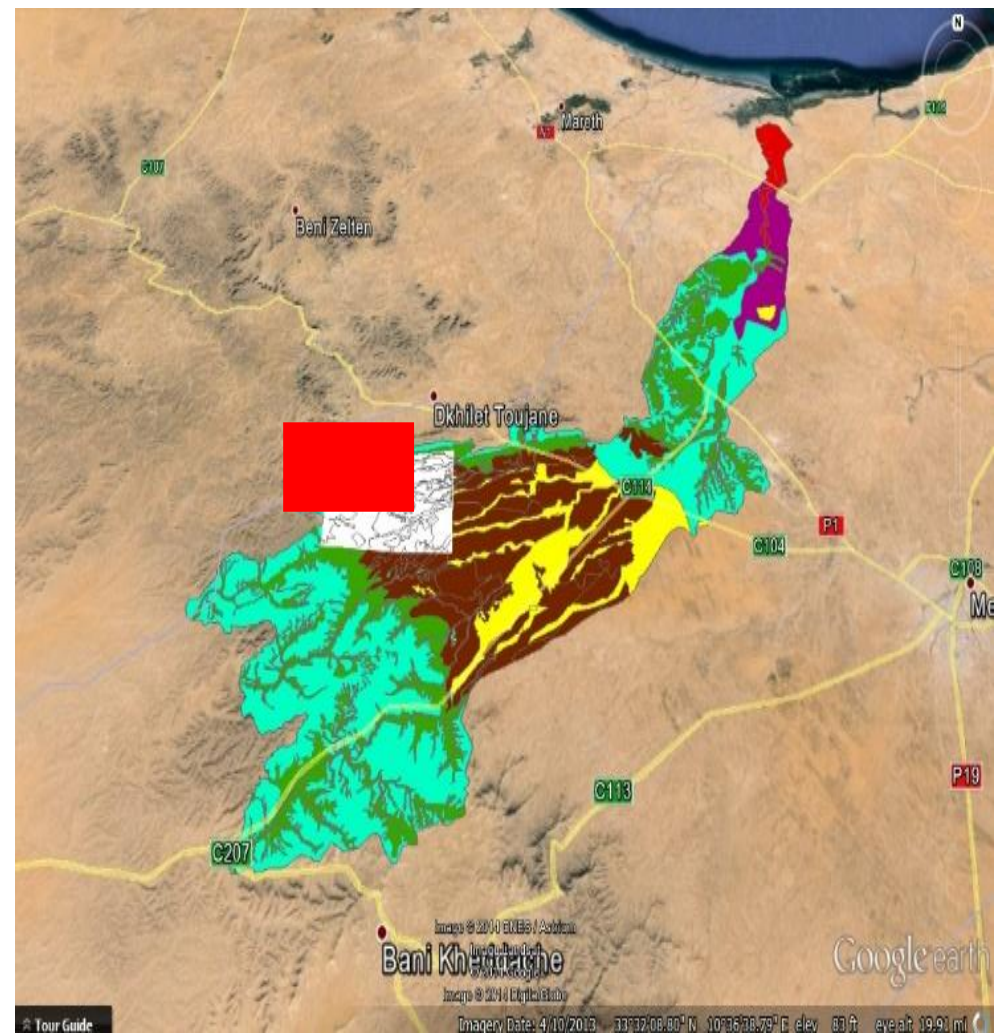

Figure 2. Red square shows the location selected for land use change study in Oum Zessar watershed (overlayed on Google Earth satellite image).

Table 1. Summary of selected vegetation indices reported in the literature derived from multispectral satellite images

\begin{tabular}{lccc}
\hline Vegetation Index & Abbreviation & Equation & Reference \\
\hline Difference Vegetation Index & DVI & NIR $-\mathrm{R}$ & (Tucker, 1979) \\
Green Difference Vegetation Index & GDVI & NIR $-\mathrm{G}$ & (Sripada et al., 2006) \\
Green Normalized Difference Vegetation Index & GNDVI & $(\mathrm{NIR}-\mathrm{G}) /(\mathrm{NIR}+\mathrm{G})$ & (Buschmann and Nagel, 1993) \\
Normalized Difference Vegetation Index & $\mathrm{NDVI}$ & $(\mathrm{NIR}-\mathrm{R}) /(\mathrm{NIR}+\mathrm{R})$ & (Rouse et al., 1974) \\
Normalized Green & $\mathrm{NG}$ & $\mathrm{G} /(\mathrm{NIR}+\mathrm{G}+\mathrm{R})$ & (Sripada et al., 2006) \\
Normalized Red & $\mathrm{NR}$ & $\mathrm{R} /(\mathrm{NIR}+\mathrm{G}+\mathrm{R})$ & (Sripada et al., 2006) \\
Normalized Near Infrared & $\mathrm{NNIR}$ & $\mathrm{NIR} /(\mathrm{NIR}+\mathrm{G}+\mathrm{R})$ & (Sripada et al., 2006) \\
Ratio Vegetation Index (Simple Ratio) & $\mathrm{RVI}$ & $\mathrm{NIR} / \mathrm{R}$ & (Birth and McVey, 1968) \\
\hline
\end{tabular}

\section{RESULTS AND DISCUSSION}

The pre-processing stage of the satellite images included applying eight different vegetation indices (VIs) to the images in order to enhance the classification process (Figure 5). Five of the VIs (DVI, GDVI, GNDVI, NDVI, RVI) were based on only two image bands while the other three VIs (NG, NR, NNIR) were based on three image bands. Some of the VIs did not show clear differences between the different land uses and therefore these VIs were not useful for the classification stage. During the classification procedure, only three VIs showed high significance to be used for the recognition of the different objects and classes. These indices are Normalized Difference Vegetation Index (NDVI), Normalized Near Infrared (NNIR) and Ratio Vegetation Index (RVI). NDVI was helpful to distinguish between plants and other land uses and then later to classify the olive trees. NNIR was used to classify the objects belong to the urban class. Finally, RVI was used also to recognize green plants and bare soil objects. The equations of the three VIs (NDVI, NNIR, RVI) are constructed manly based on the NIR and Red bands which indicates the potential of those bands for object-based land use classification. 


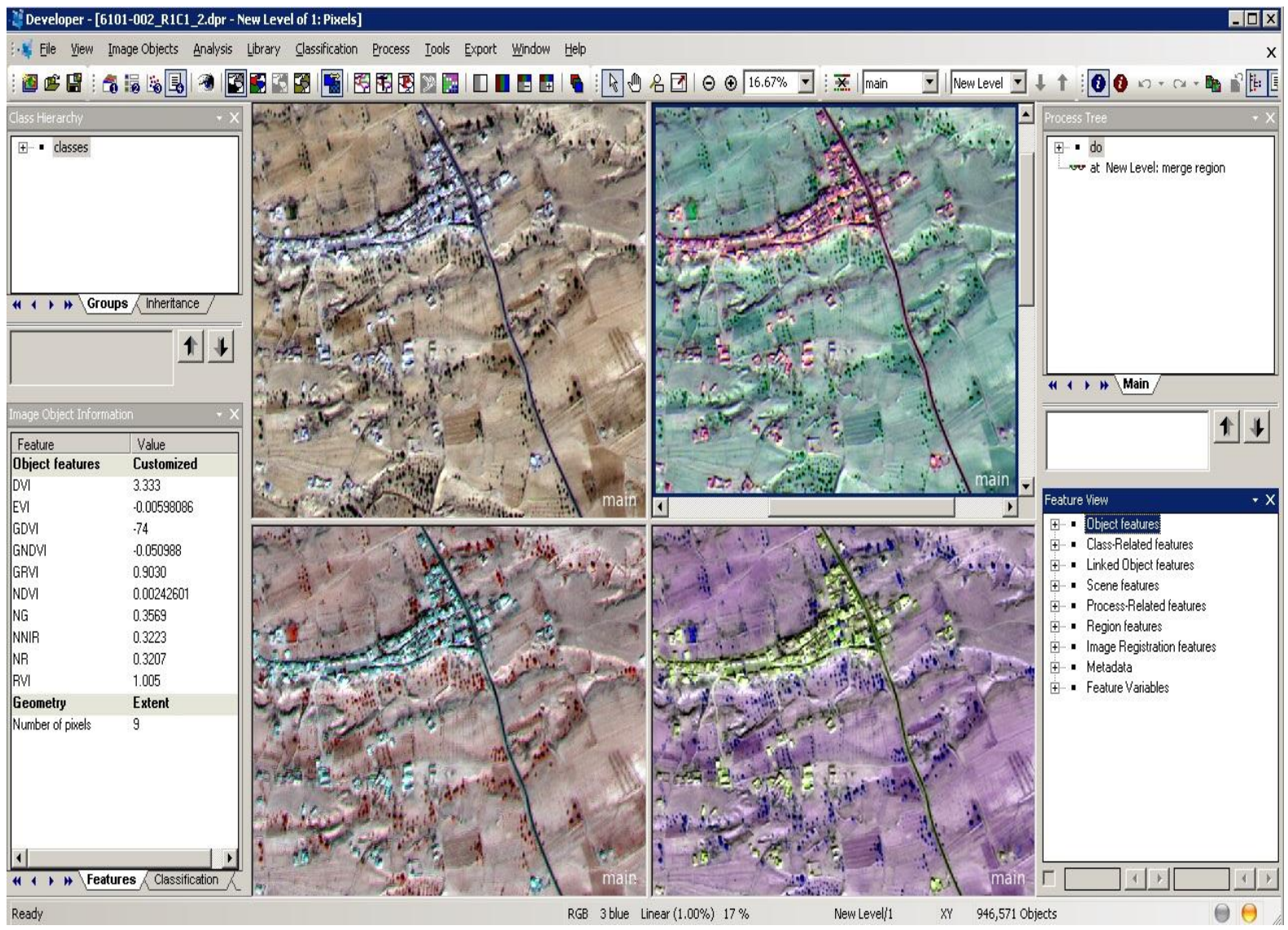

Figure 3. Screenshot of the recognition software applying the Geographic object-based image analysis technique

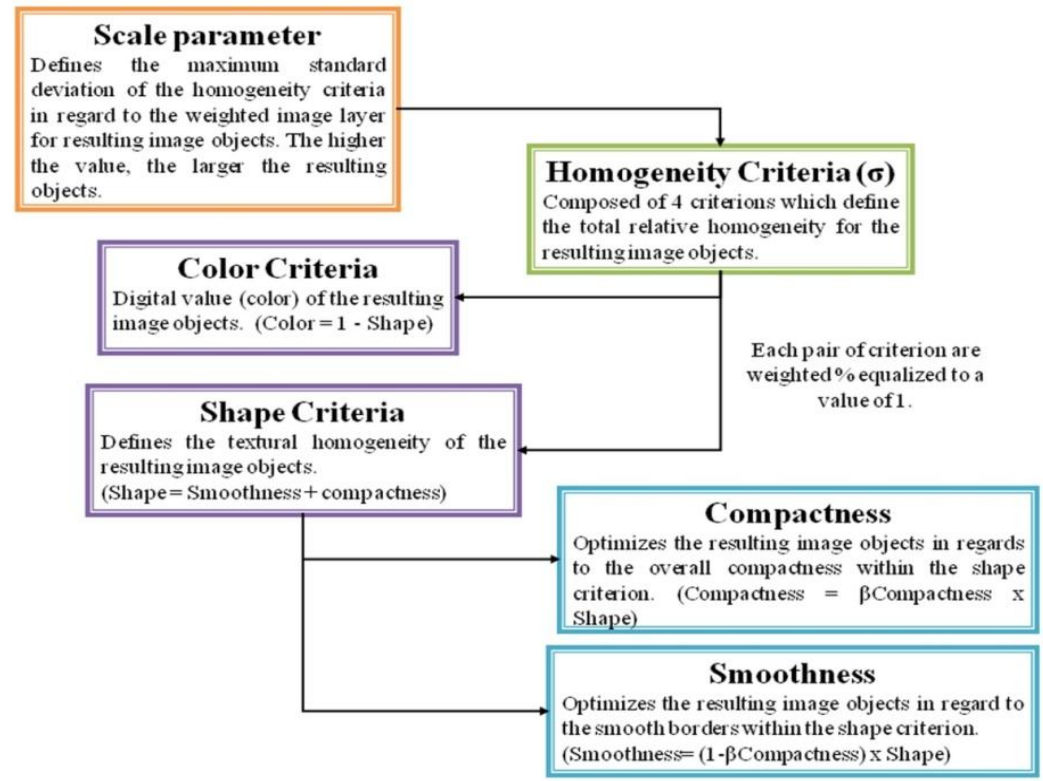

Figure 4. Multi-resolution segmentation concept flow diagram for the recognition software 

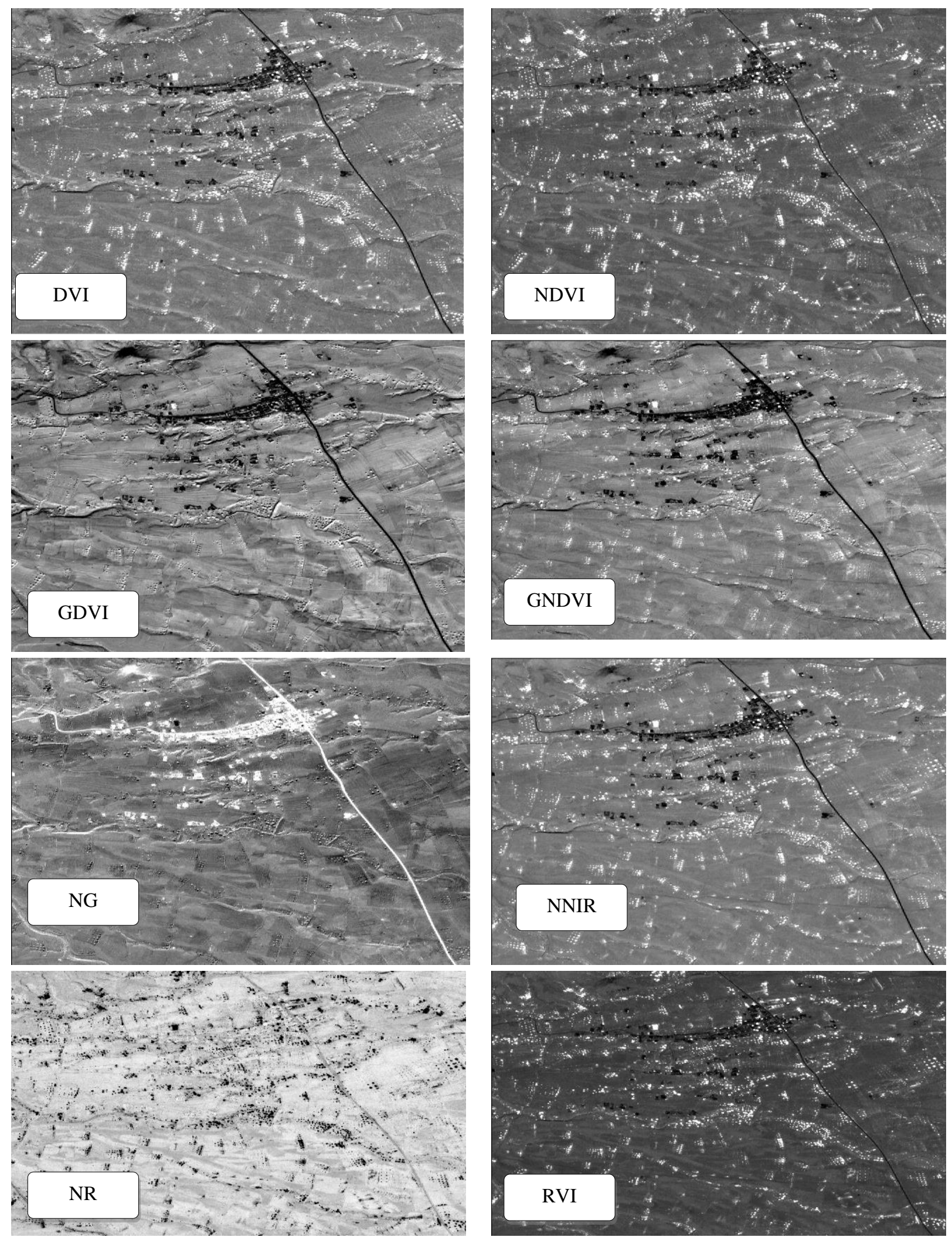

Figure 5. Illustration of the eight different vegetation indices (VIs) applied to the 2013 satellite image. 
The multi-resolution segmentation algorithm was selected as the main segmentation algorithm through the entire classification process (Appendix 1). The scale defines the maximum standard deviation of the homogeneity criteria for the resulting image objects, while the homogeneity criterion defines the characteristics of the objects (Trimble, 2011). Figure (6) shows a comparison test for the four homogeneity criteria (shape, color, smoothness and compactness) embedded in the multi-resolution segmentation algorithm. A multi-resolution segmentation process with the same scale of 90 was applied four times with different weights for shape and compactness criteria to study the effect of deferent weights on the final segmentation results. The weight of 0.5 means equal magnitude to both the criteria under investigation. For example, if the shape weight is 0.5 means that equal importance has been given to both shape and color criteria. While, if the shape weight is 0.8 means that a weight of 0.2 has been given to the color criteria. The same is in case of the compactness and smoothness criteria (Gennaretti et al., 2011). Assigning different values to these segmentation parameters produces different sizes and shapes of image objects. Therefore, it is a critical decision to choose these parameters values to acquire the maximum accuracy in segmentation. Based on the procedure proposed by (Meinel and Neubert, 2004; Neubert et al., 2006), the most favorable values of segmentation parameters were selected through comparison between manually extracted sample polygons and objects derived from different segmentations. The optimal segmentation parameters values are a compromise between a reduced number of the resulting image objects and a high-quality division of the surface in land cover classes. Finally, All the potential combinations of segmentation Parameters were tested, and the most favorable parameters values were selected.
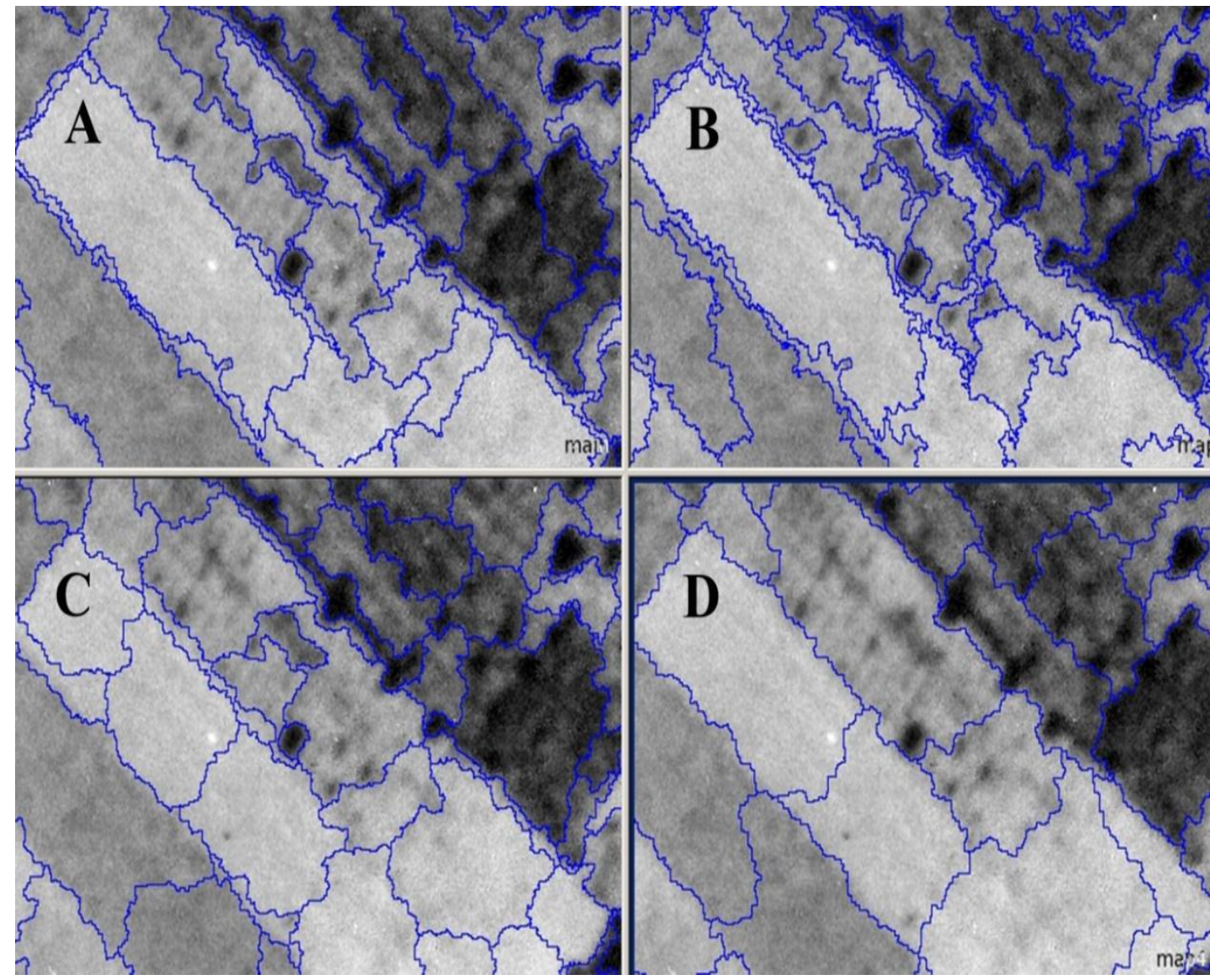

Figure 6. Comparison between multi-resolution segmentation algorithms with the same value for scale parameter as 90 and different weights of shape and compactness: a) shape 0.5 and compactness 0.2 ; b) shape 0.2 and compactness 0.5 ; and c) shape 0.5 and compactness 0.8 , (D) shape 0.8 and compactness 0.5 . 
After the segmentation process, the classification phase was carried out. Three land use and land cover classes were recognized during the classification progression (Olives, Urban areas, Bare soil and other Vegetation types). Bare soil and other Vegetation classes were joined in one class during the classification process because they are not affecting the study parameters. Successive approach was followed during the classification as the different classes were classified in a sequential order. The spatial analysis of the generated land use and land cover classification maps (Figure 7) showed slightly to moderate growth in the area of olive plantation in the study area. The main change can be attributed to the growth in the trees size with the same number of trees in the field. The other source of change is the new plantation of the olive trees in the study area, which was low to very low percentage. On the other hand, urbanization processes have been found in the study area in various locations.
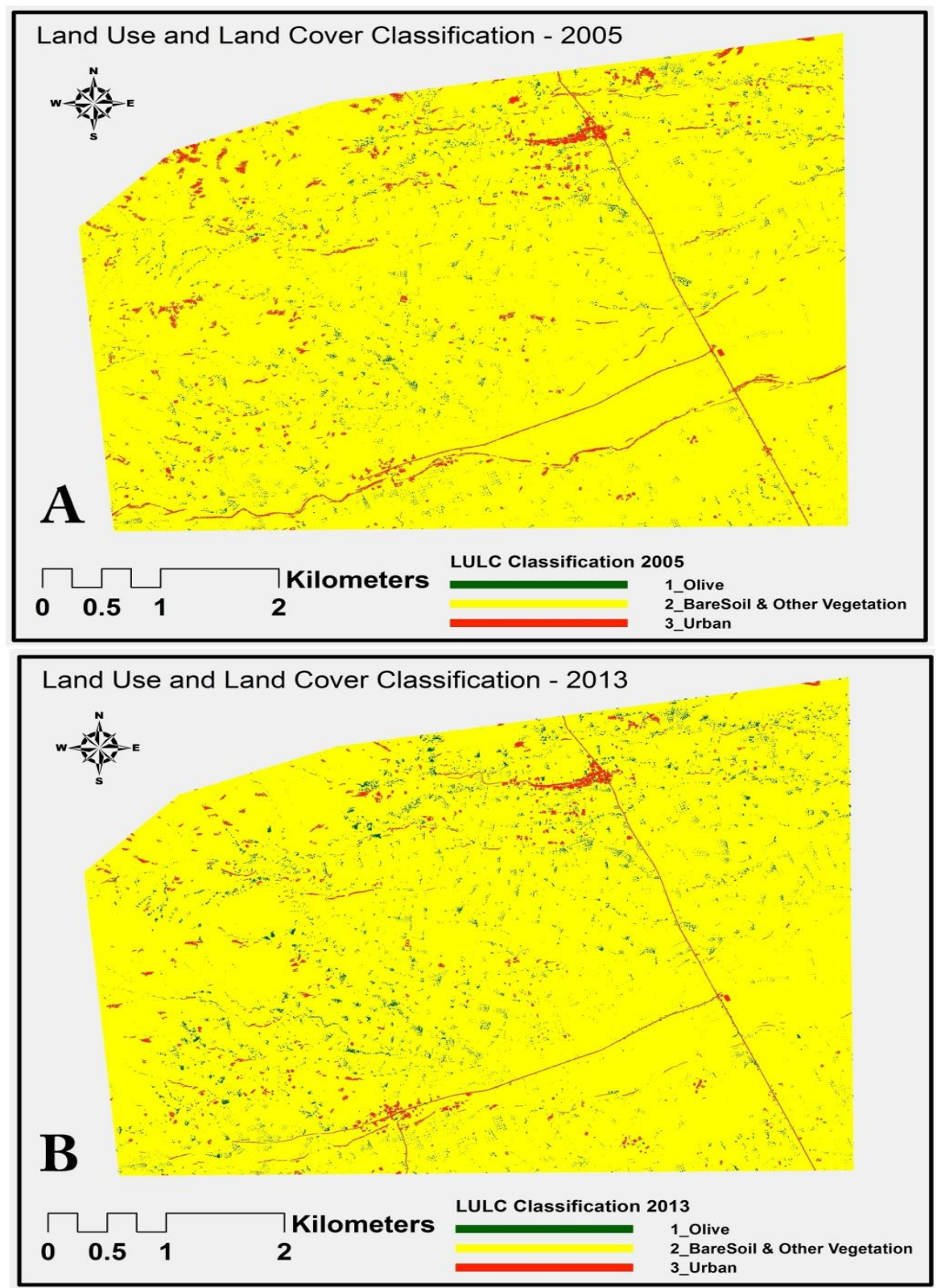

Figure 7. classification maps show the land use classes in the study area during two different years A. 2005 and B. 2013 
Table (2) shows the results of the change detection analysis for the olive trees canopy in the study area during the period from 2005 to 2013. The results demonstrate that the olive tree canopy increased by almost $60 \%$ from 39 ha to 62 ha during the period from 2005 to 2013. In addition, analysis of the classification results showed that the number of the trees objects increased by $22.7 \%$ from the year 2005 to 2013. A comparison between different sizes of the olive trees is shown in Figure (8). The results illustrate that small objects (less than $4 \mathrm{~m}^{2}$ in diameter) which refer to the small olive trees were much greater in number in 2005 than 2013. This may show that planting new trees in 2005 was more active than 2013. This can be explained as a change in the producers' preferences or as an economic reason. Finally, these results showed the capability of Geographic object-based image analysis" (GEOBIA) technique in land use classification in general and in detecting olive trees objects specifically.

Table 2. Changes in olive trees canopy in the study area during the period from 2005 to 2013

\begin{tabular}{lccc}
\hline Parameter & Year 2005 & Year 2013 & Change Rate \\
\hline olive Canopy (ha) & 39.08 & 62.31 & +23.23 ha \\
$(+59.42 \%)$ \\
Number of Trees objects & 9836 & 12069 & +2233 objects \\
$(+22.7 \%)$
\end{tabular}

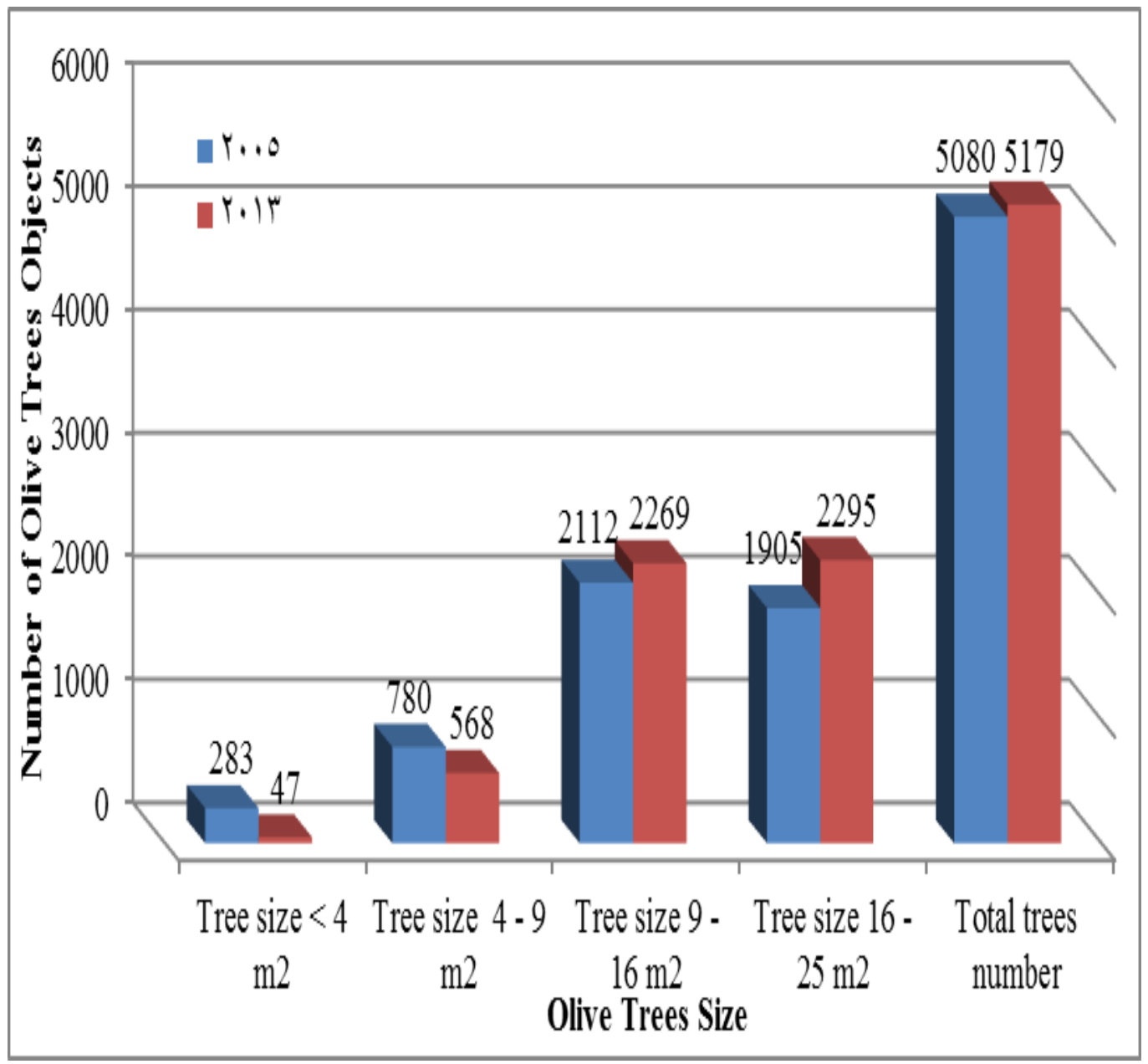

Figure 8: Comparison of the number of olive trees objects at different olive trees sizes in 2005 and 2013 


\section{CONCLUSION}

The study showed that vegetation indices (VIs) may perform differently in distinguishing land use classes based on the image bands involved in the calculation of the VI. In this study, NDVI, NNIR, RVI showed superior performance in recognizing olive trees objects and other land use classes. In addition, the multiresolution segmentation algorithm, which is one of the main algorithms for object-based classification, showed outstanding performance in delineating object segmentation in the study area. The change detection classification showed that olive tree canopy increased by almost $60 \%$ from 39 ha to 62 ha and the number of the tree's objects increased by $22.7 \%$ in the study area during the period from 2005 to 2013. However, this increase was mainly due to the size growth of the olive trees and not due to new plantations. These results illustrated that Geographic object-based image analysis" (GEOBIA) technique successfully detected olive tree objects and was able to detect changes in time. Finally, future work will focus on applying the developed classification technique on other crops and land use classes.

\section{ACKNOWLEDGMENTS}

This work has been supported by the Italian Ministry for Foreign Affairs, which financed the visit of nonItalian members of the authors team to visit Italy for 6 months under "Diplomacy" Program, giving the chance to collaborate with the Italian team in order to achieve this study._Also, the authors appreciate the technical and logistic support from the SPACE Center (Sustainable Production and Adaptation to Climate Change Effects center) at Faculty of Agriculture, Damanhour University during the production of this publication.

\section{REFERENCES}

Adham, A., M. Riksen, M. Ouessar and C.J. Ritsema. 2016a. A Methodology to Assess and Evaluate Rainwater Harvesting Techniques in (Semi-) Arid Regions. Water .8, 198

Adham, A., J.G. Wesseling, R. Abed, M. Riksen, M. Ouessar and C.J. Ritsema. 2019. Assessing the impact of climate change on rainwater harvesting in the Oum Zessar watershed in Southeastern Tunisia. Agricultural Water Management. 221, 131-140.

Adham, A., J.G. Wesseling, M. Riksen, M. Ouessar and C.J. Ritsema. 2016b. A water harvesting model for optimizing rainwater harvesting in the wadi Oum Zessar watershed, Tunisia. Agricultural Water Management .176, 191-202.
Allaya, M., M. Pradeilles and I. Debabi. 2001. "MEDAGRI: annuaire des économies agricoles et alimentaires des pays méditerranéens et arabes," CIHEAM.

Antrop, M. 2005. Why landscapes of the past are important for the future. Landscape and urban planning. 70, 21-34.

Baret, F and G. Guyot .1991. Potentials and limits of vegetation indices for LAI and APAR assessment. Remote sensing of environment. 35, 161-173.

Birth, G.S and G.R. McVey. 1968. Measuring the color of growing turf with a reflectance spectrophotometer 1. Agronomy Journal .60, 640-643.

Buschmann, C and E. Nagel. 1993. In vivo spectroscopy and internal optics of leaves as basis for remote sensing of vegetation. International Journal of Remote Sensing. 14, 711-722.

Chen, X., L. Vierling and D. Deering. 2005. A simple and effective radiometric correction method to improve landscape change detection across sensors and across time. Remote Sensing of Environment. 98, 63-79.

Cihlar, J and L.J. Jansen. 2001. From land cover to land use: a methodology for efficient land use mapping over large areas. The Professional Geographer .53, 275-289.

Derouiche, R. 1997. Contributiona l'étude par modele numérique de l'impact des aménagements de CES sur la recharge de la nappe de Zeuss-Koutine. Mémoire de in d'études, INAT $\mathbf{6 8}$.

Ellis, E and R. Pontius. 2013. Land-use and land-cover change. In "Encyclopedia of Earth" (C. J. Cleveland, ed.). Environmental Information Coalition, National Council for Science and the Environment, Washington, D.C.

ESRI ArcGIS, D. 2011. Release 10. Redlands, CA: Environmental Systems Research Institute .437, 438.

Etter, A., C. McAlpine, D. Pullar and H. Possingham. 2006. Modelling the conversion of Colombian lowland ecosystems since 1940: Drivers, patterns and rates. Journal of environmental management. 79, 74-87.

Ewert, F., M. Rounsevell, I. Reginster, M. Metzger and R. Leemans. 2005. Future scenarios of European agricultural land use: I. Estimating changes in crop productivity. Agriculture, Ecosystems \& Environment .107, 101-116.

Gennaretti, F., M.N. Ripa, F. Gobattoni, L. Boccia and R. Pelorosso. 2011. A methodology proposal for land cover change analysis using historical aerial photos. Journal of Geography and Regional Planning. 4, 542-556.

Gitelson, A.A., Y.J. Kaufman, R. Stark and D. Rundquist 2002. Novel algorithms for remote estimation of vegetation fraction. Remote Sensing of Environment .80, 76-87. 
Gregrio, A and J. Jansen. 2000. Land cover classification system (LCCS); Classification concepts and user manual for software version 2.

Jansen, L.J. 2006. Harmonization of land use class sets to facilitate compatibility and comparability of data across space and time. Journal of Land Use Science 1, 127-156.

Jensen, J. 1996. Introductory Digital Image Processing A Remote Sensing Perspective. pp. 318. Prentice Hall, Saddle River, NJ.

Lu, D., P. Mausel, E. Brondizio and E. Moran. 2004. Change detection techniques. International journal of remote sensing .25, 2365-2401.

Meinel, G and M. Neubert .2004. A comparison of segmentation programs for high resolution remote sensing data. International Archives of Photogrammetry and Remote Sensing .35, 10971105.

Meyer, W.B., W.B. Meyer and I. BL Turner. 1994 "Changes in land use and land cover: a global perspective," Cambridge University Press.

Neubert, M., H. Herold and G. Meinel .2006. Evaluation of remote sensing image segmentation qualityfurther results and concepts. International Archives of Photogrammetry, Remote Sensing and Spatial Information Sciences. 36.
Ouessar, M. 2007. "Hydrological impacts of rainwater harvesting in wadi Oum Zessar watershed (Southern Tunisia)," Ghent University.

Rabia, A.H and F. Terribile. 2013. Semi-Automated Classification of Gray Scale Aerial Photographs using Geographic Object Based Image Analysis (GEOBIA) Technique. In "European Geosciences Union (EGU) General Assembly", Vienna, Austria.

Ripa, M.N., A. Leone, M. Garnier and A.L. Porto .2006. Agricultural land use and best management practices to control nonpoint water pollution. Environmental Management .38, 253-266.

Rouse, J., R.H. Haas, J.A. Schell and D.W. Deering. 1974. Monitoring vegetation systems in the Great Plains with ERTS. NASA special publication $\mathbf{3 5 1}$, 309.

Sripada, R.P., R.W. Heiniger, J.G. White and A.D. Meijer. 2006. Aerial color infrared photography for determining early in-season nitrogen requirements in corn. Agronomy Journal .98, 968-977.

Trimble, T. 2011. ECognition Developer 8.7 Reference Book. Trimble Germany GmbH: Munich, Germany, 319-328.

Tucker, C.J. 1979. Red and photographic infrared linear combinations for monitoring vegetation. Remote sensing of Environment .8, 127-150. 


\section{Appendix 1}

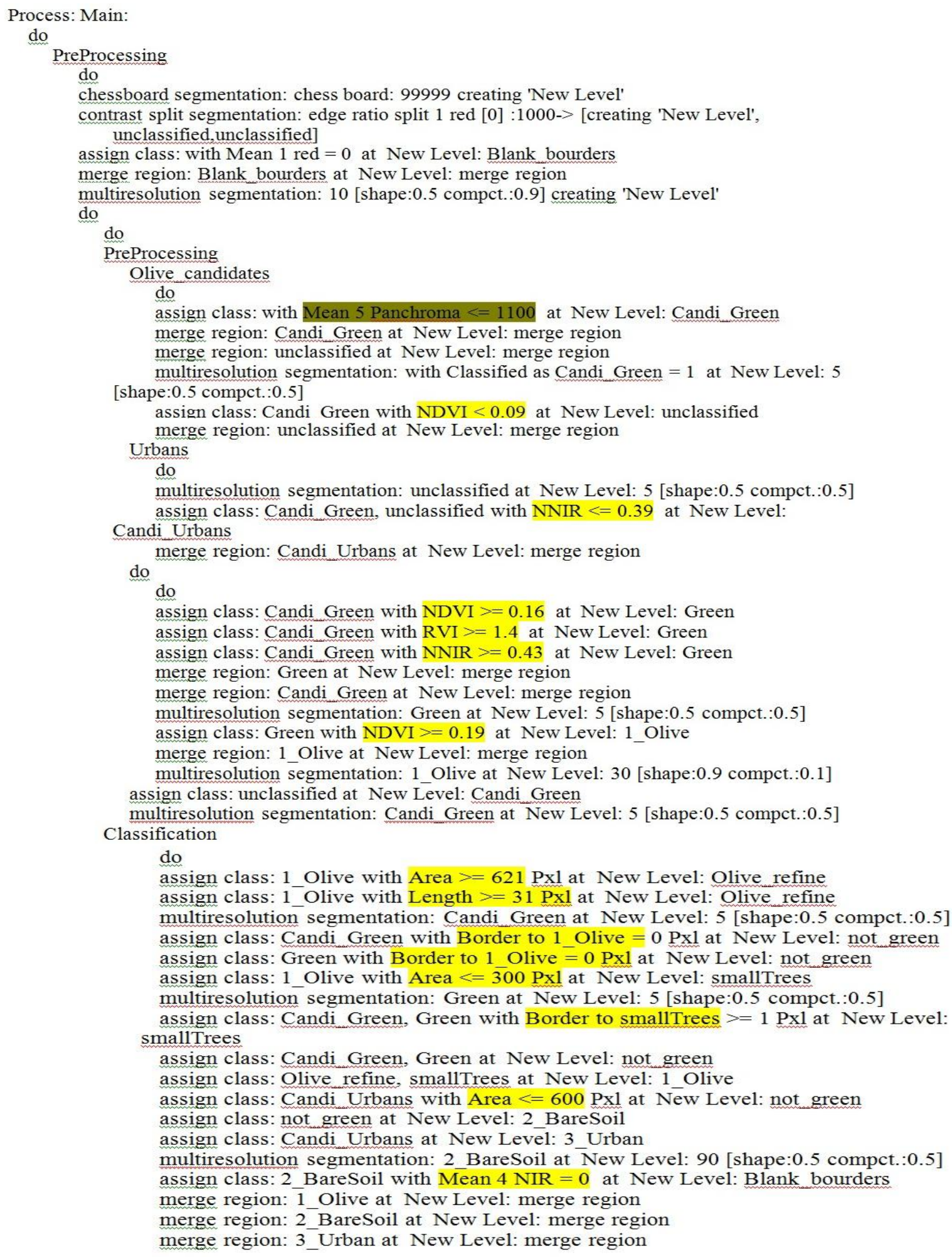




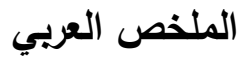

\section{تغيير توزيع أثجار الزيتون باستخدام تصنيف الصور شبه الآلي القائم على تقسيم الصورة الفضائية}

أحمد حرب ربيع، عماد فوزي عبد العاطي، مها لطفي السيد، عاصم عبد المنعم أحمد محمد، فاطمة وسار، إدواردو فيوريللو،

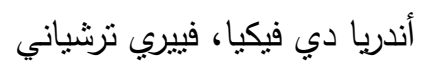

النتائج أن دليل الغطاء النباتي (NDVI) والأشعة تحت الحمراء القريبة (NNIR) ودليل النسبة النباتية (RVI) كان لهاءئ أهمية عالية لإستخدامها في التعرف على الكائنات والفئات

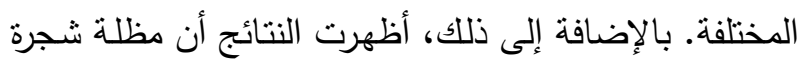

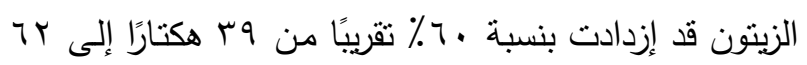

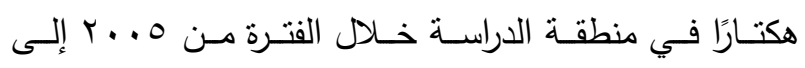

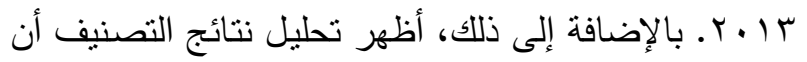

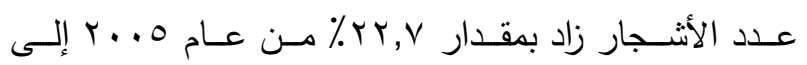

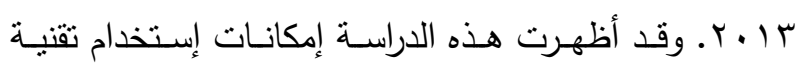
تحليل الصور المتمد على الكائنات الجغرافية (GEOBIA)" في تصنيف إستخدامات الأراضي بشكل عام وفي الكثف الكف عن أثجار الزيتون بثكل خاص. الكلمـات الففتاحيـة: الإستنــعار عـن بعـد، GEOBIA،

الزيتون، دلائل الغطاء النباتي، تغير إستخدامات الأراضي.
تحليل الصور المعتمد على الهدف الجغرافي (GEOBIA)

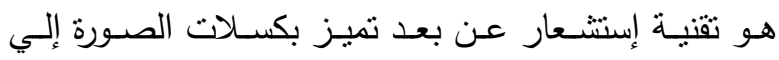

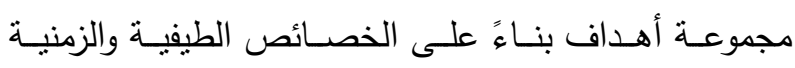

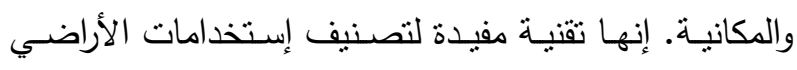

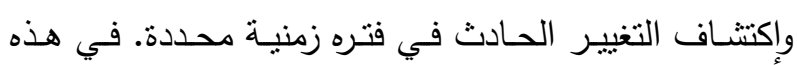

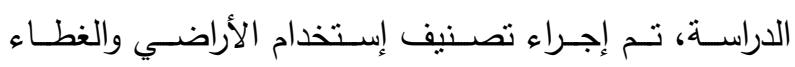
الأرضي وكثف التغيير لنقدير التغيرات في توزيـع أثنجار

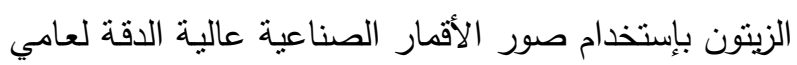

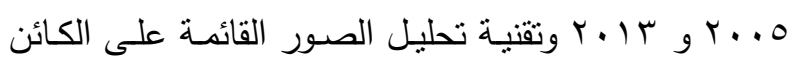
الجغرافي . تم إستخدام ثمانبة دلائل نباتية مختلفة لتعزيز عملية التصنيف. تم إختيار خوارزمية التجزئة متعددة الدقة كخوارزمية التجزئة الرئيسية من خـال عملية الفية التصنيف بأكملها. وقد أظهرت 